IZA DP No. 8626

Trends in the Returns to Social Assimilation:

Earnings Premiums among U.S. Immigrants that Marry Natives

Delia Furtado

Tao Song

November 2014 


\title{
Trends in the Returns to Social Assimilation: Earnings Premiums among U.S. Immigrants that Marry Natives
}

\author{
Delia Furtado \\ University of Connecticut \\ and IZA \\ Tao Song \\ University of Connecticut
}
Discussion Paper No. 8626
November 2014

\author{
IZA \\ P.O. Box 7240 \\ 53072 Bonn \\ Germany \\ Phone: +49-228-3894-0 \\ Fax: +49-228-3894-180 \\ E-mail: iza@iza.org
}

\begin{abstract}
Any opinions expressed here are those of the author(s) and not those of IZA. Research published in this series may include views on policy, but the institute itself takes no institutional policy positions. The IZA research network is committed to the IZA Guiding Principles of Research Integrity.

The Institute for the Study of Labor (IZA) in Bonn is a local and virtual international research center and a place of communication between science, politics and business. IZA is an independent nonprofit organization supported by Deutsche Post Foundation. The center is associated with the University of Bonn and offers a stimulating research environment through its international network, workshops and conferences, data service, project support, research visits and doctoral program. IZA engages in (i) original and internationally competitive research in all fields of labor economics, (ii) development of policy concepts, and (iii) dissemination of research results and concepts to the interested public.
\end{abstract}

IZA Discussion Papers often represent preliminary work and are circulated to encourage discussion. Citation of such a paper should account for its provisional character. A revised version may be available directly from the author. 
IZA Discussion Paper No. 8626

November 2014

\section{ABSTRACT \\ Trends in the Returns to Social Assimilation: Earnings Premiums among U.S. Immigrants that Marry Natives}

Previous studies show that immigrants married to natives earn higher wages than immigrants married to other immigrants. Using data from the 1980-2000 U.S. censuses and the 20052010 American Community Surveys, we show that these wage premiums have increased over time. Our evidence suggests that the trends cannot be explained by changes in the attributes of immigrants that tend to marry natives but are instead most likely a result of increasing returns to the characteristics of immigrants married to natives. Because immigrants married to natives tend to have more schooling, part of the increasing premium can be explained by increases in the returns to a college education. However, we find increasing intermarriage premiums even when allowing the returns to schooling as well as English-speaking ability to vary over time. We believe these patterns are driven by changes in technology and globalization which have made communication and management skills more valuable in the U.S. labor market.

JEL Classification: J12, J24, J31, J61

Keywords: intermarriage, wage premium, immigration, globalization

Corresponding author:

Delia Furtado

Department of Economics

University of Connecticut

365 Fairfield Way, Unit 1063

Storrs, CT 06269-1063

USA

E-mail: Delia.Furtado@uconn.edu 


\section{Introduction}

Immigrants married to natives tend to be more socially integrated than immigrants married to other immigrants. In the U.S., they typically have better English language skills and know more about U.S. customs and culture both because immigrants with these skills are more likely to marry natives and because sharing a household with a native brings on further social integration. In the past few decades, the labor market returns to communication and managerial skills have increased as a result of technological change--specifically computerization--and globalization (Acemoğlu and Autor, 2011). We hypothesize then that wage premiums associated with marrying natives have increased over time. In this paper, we start by examining whether the differential between hourly wages of immigrants married to natives and immigrants married to other immigrants has changed in recent decades. We then explore whether changes in observable characteristics of immigrants that choose to marry natives can explain trends in this differential. Next, we test whether the general patterns are robust across education groups and races. Finally, we explore how much of the increasing marriage to a native premium might be explained by increasing returns to education and English-speaking ability in the U.S. economy.

It has been well established in the literature that immigrants married to natives have better labor market outcomes than immigrants married to other immigrants. Intermarriage ${ }^{1}$ wage premiums have been found for immigrants in Australia (Meng and Gregory, 2005), the U.S. (Kantarevik, 2005; Chi and Drewianka, 2010), France (Meng and Meurs, 2009), Germany (Nottmeyer, 2010), Sweden (Dribe and Nystedt, 2014; Nekby, 2010) and the Netherlands

\footnotetext{
${ }^{1}$ In this paper, we use intermarriage synonymously with "marriage to a native" regardless of whether the native is from a different country of origin. Our most recent data (2007-2010 American Community Survey) suggest that 82.3 percent of the immigrants that marry other immigrants marry immigrants from the same country of origin. With our data, we are not able to determine whether the natives married to immigrants have a parent or grandparent from the same country as the immigrant, but Duncan and Trejo (2011) show using Current Population Survey data that ethnic attrition is substantial among thirdgeneration Mexicans with only 17 percent of third-generation Mexican children having a majority of their grandparents born in Mexico.
} 
(Gevrek, 2011). Immigrants married to natives are also more likely to be employed (Gevrek, 2011; Furtado and Theodoropoulos, 2009).

There is disagreement in this literature, however, about whether marriage choice has a causal impact on labor market outcomes or whether unobservable characteristics, such as ambition or general comfort with the host country's language, customs, laws, and institutions, increase the likelihoods of marriage to a native and labor market success. Taking instrumental variables approaches which exploit plausibly exogenous variation in the opportunities for marrying natives (driven by the size of the immigrant population and sex ratios within marriage markets), several papers find that intermarriage premiums persist even when steps are taken to control for the unobservable characteristics of the immigrants that choose to marry natives (Meng and Gregory, 2005; Meng and Meurs, 2009; Furtado and Theodoropoulos, 2009). This may not be surprising given that a native spouse and the native networks acquired through marriage can accelerate an immigrant's language proficiency, improve understanding of social and cultural customs, and provide information about local labor markets. Furtado and Theodoropoulos (2010) provide several pieces of evidence suggesting that employment probabilities are higher for immigrants married to natives as a result of access to native networks that are helpful in the job search process. On the other hand, using a similar instrumental variables approach, Kantarevic (2005) finds that the intermarriage wage premium disappears in the U.S. when steps are taken to control for omitted variables and reverse causality.

The validity of all of these instrumental variables-based studies rests on the assumption that marriage market characteristics do not have direct impacts on labor market outcomes for reasons unrelated to marriage choices. Questioning this assumption, several papers instead examine earnings profiles of immigrants before and after they marry to determine whether earnings jump post-marriage or whether the immigrants that eventually marry natives always had higher earnings (Dribe and Nystedt, 2014; Nottmeyer, 2010; Nekby, 2010). They typically do not find dramatic earnings jumps for immigrants married to natives relative to those who marry other 
immigrants; immigrants married to natives always have higher earnings. This may be because the majority of benefits from marrying a native start during the courting period as opposed to post marriage as would be the case for access to native networks. It may also be that the labor market returns to improved knowledge of host country language and social customs can only be observed many years after marriage and existing studies do not follow couples for long enough. ${ }^{2}$

For the purposes of our study, it does not matter whether marriage choice affects earnings or instead earnings (and characteristics associated with earnings) affect marriage choice. What matters is that the immigrants married to natives tend to have better overall social and communication skills in the host society. By examining how intermarriage premiums have changed over time, we can gain insight into how the returns to these skills have changed despite not having direct measures of linguistic and social skills in the data.

Technological change, international trade, and international offshoring of jobs have resulted in big changes in U.S. labor markets in the past few decades. Routine tasks once performed by workers with average skill levels in the U.S. are now carried out by computers and low-wage workers in other countries. Consequently, there has been an increase in labor market demand for workers who perform non-routine tasks that involve in-person interactions, situational adaptability, and persuasive or managerial skills (Autor, Levy, and Murnane, 2003; Weinberger, forthcoming). Autor and Dorn (2013) find that local labor markets that historically specialized in non-routine tasks experienced earnings growth at the tails of skill distribution with low-skilled laborers moving into the service sector starting in the 1980s. In fact, between 1980 and 2005, the share of hours worked in the service sector among non-college workers has increased more than

\footnotetext{
${ }^{2}$ Nekby (2010) considers wage impacts three years before the marriage and two years after, while Nottmeyer (2010) uses an unbalanced panel of data from 1984 to 2007. Dribe and Nystedt (2014) look at earnings profiles ten years before and ten years after marriage. They find that, in general, immigrants who eventually marry natives earn higher wages well before marriage. However, immigrants from the Middle East and North Africa show no evidence of an intermarriage premium before marriage but earn substantial premiums post-marriage. The authors explain that this may be either because immigrants from these areas have the most to gain from intermarriage or because they are less likely to have significant contact with future spouses before marriage.
} 
53.5 percent (Autor and Dorn, 2013). In addition, Acemoğlu and Autor (2011) show that the share of employment in high skilled non-routine cognitive-intensive professional, managerial, and technical occupations increased by 62.7 percent between 1959 and 2007. This process through which employment is increasingly concentrated at the top and bottom of the wage distribution has been referred to in the literature as “job polarization”. Because immigrants married to natives are more likely to possess the social interactions skills that are becoming relatively more highly rewarded in the economy, we expect intermarriage earnings premiums to have increased in the past three decades.

Using data from the 1980-2000 U.S. censuses and the 2005-2010 American Community Surveys, we find increasing hourly wage premiums for immigrants married to natives relative to those married to immigrants. Given how robust it is to adding more and more observable characteristics as controls in our models, this trend does not seem to be driven by changing characteristics of immigrants that choose native spouses. Since social and managerial skills appear to have become relatively more highly rewarded across the skill distribution (Autor and Handel, 2013), it should not be surprising that intermarriage premiums have increased for immigrants of all education levels. Interestingly, trends are driven completely by whites and Hispanics; there is no relationship between marriage choice and hourly wages for blacks and Asians. We also show that increasing returns to a college degree can explain part, but not all, of the increasing intermarriage premium.

The remainder of this paper is organized as follows. Section 2 presents the data and describes the empirical model used in the analysis. Section 3 discusses baseline results, examines whether patterns are robust across demographic groups, and provides some insight into why marriage to native premiums have increased over time. Section 4 concludes.

\section{Data and Model}


Our study draws on the Integrated Public Use Micro Samples (Ruggles et al., 2010) for the years 1980, 1990, and 2000 Censuses, and the American Community Survey (ACS) 3-year samples for 2005-2007 and 2008-2010. The Census data for 1980, 1990 and 2000 are each five percent samples of the U.S. population. The ACS 2005-2007 sample contains all observations from the 1 percent ACS samples for 2005, 2006, and 2007 while the 2008-2010 ACS sample merges 1 percent samples for 2008, 2009, and 2010. Weights are adjusted appropriately.

We restrict the sample to married (spouse present) immigrants aged 18 to 64 who are not enrolled in school, and work full time full year. ${ }^{3}$ An immigrant is defined as a person born outside of the U.S. while a native is born in one of the 50 U.S. states. In this study, people born in outlying areas such as Puerto Rico and the Virgin Islands are considered immigrants. Due to the difficulties in interpreting labor market outcomes of females, we keep only males in the sample. In order to ensure immigrants' exposure to the U.S. marriage market, we omit the immigrants who arrived in the U.S. after the age of 18. Because we want to control for local labor market conditions, we keep only immigrants residing in identified metropolitan statistical areas (MSAs). Concerned about respondents misreporting their wages, we drop individuals who report hourly wages of less than two and more than 200 dollars, measured in 1999 dollars. Finally, given our interest in measuring the effects of English language proficiency, we exclude immigrants from English-speaking countries.

Figure 1 plots hourly wages (in 1999 dollars) of immigrants married to natives and immigrants married to other immigrants in the past three decades. The figure reveals a widening wage gap, which is consistent with computerization and globalization altering the labor market returns to communication skills. It is also possible that these trends have been driven by changes in the immigrant composition over time and specifically changes in the characteristics of the immigrants that marry natives. For example, if over time, immigrants with more years of

\footnotetext{
${ }^{3}$ Full time full year work implies working 35 hours or more in a typical week and no less than 50 weeks in the previous year. This criterion is defined by the United States Census Bureau.
} 
schooling have become more likely to marry natives, then the widening wage gap may be explained by changes in the skill composition of these two groups as opposed to changes in the returns to their skills.

To address this issue, we estimate the following ordinary least squares model:

$$
W_{i c t}=\beta_{1} \text { Native }_{i k t}+\sum_{t=2}^{5}\left(\beta_{t} \text { Native }_{i c t} \cdot T_{t}\right)+\rho X_{i c t}+\delta_{c t}+\varepsilon_{i c t}
$$

where $W_{i c t}$ is the $\log$ hourly wage of immigrant $i$ living in city $c$ in year $t$. We use a dummy variable Native to identify whether the immigrant has native spouse. The vector $X$ contains the individual-level controls age, age squared, educational achievement, ${ }^{4}$ presence of children in the household, residence in the central city section of the MSA, English fluency, ${ }^{5}$ years living in the U.S, and measures of the size of the immigrant's group residing in his MSA. City-year fixed effects, $\delta$, control for characteristics, such as the unemployment rate or industry-structure of a city, which affect everyone living in the same city in the same year. Our variables of interest are a set of interactions between Native and year dummy variables denoted $T_{t}$ where $t=2,3 \ldots 5$ represents 1990, 2000, 2005-2007, and 2008-2010 respectively. If the returns to marrying a native are positive and increasing every year, then $\beta_{5}$ should be greater than $\beta_{4}$ which should exceed $\beta_{3}$ and so forth. All of these coefficients are expected to have a positive sign.

\section{Empirical Results}

\subsection{Baseline Regressions}

Table 1 presents estimates of the effect of marriage to a native on log hourly wage rates of immigrants using several different model specifications. The first column reproduces the information in Figure 1 by showing results from the simplest possible specification without any

\footnotetext{
${ }^{4}$ We use dummy variables to measure whether immigrants have a high school diploma, some college, and at least a college degree. Less than a high school degree is the omitted category.

${ }^{5}$ This variable is measured with a dummy variable equaling 1 if the immigrant self-reports speaking only English, speaking English very well, or speaking English well and zero otherwise.
} 
control variables. The estimates show that in 1980, immigrants married to natives had 17.1 percent higher earnings than immigrants married to other immigrants. The gap increases to 21.3 percent in 1990, 28.0 percent in 2000, 29.3 percent in 2005-2007, and 29.4 percent in 2008-2010.

As discussed previously, these marriage to a native wage premiums may indicate causal impacts of association with a native spouse on wages or simply reflect that characteristics that are valued by natives in the marriage market are also valued in the labor market. Since we are using marriage to a native simply as a measure of social and communication skills, distinguishing between these explanations is not important. Instead, the challenge in our study is determining whether immigrants that marry natives are becoming more highly rewarded because fundamentals of the economy have changed or because the types of immigrants that marry natives have changed. For example, if only highly educated immigrants marry natives in in the 2000s while immigrants of all education levels marry natives in 1980, then increases in the wage effects of marrying a native may simply be explained by changes in the educational qualifications of the immigrants that marry natives.

To address this issue, in column 2, we add controls for age, education, existence of children in the household, veteran status, language fluency, and years in the U.S.. Estimated coefficients on control variables are consistent with the existing literature: wages generally increase with age but at a decreasing rate, more education increases wages, veterans and fathers have higher wages, and immigrants who have better English skills earn more as do immigrants who have lived in the U.S. for a longer time. When these variables are added to the model, estimates of the coefficients on the intermarriage variables decrease but are still positive and increasing over the years. This suggests that immigrants' changing human capital and assimilation characteristics do not fully explain the increasing wage premium.

During the period in our study, immigrants have been increasingly moving to places previously inhabited by very few immigrants; these "new destinations" are often small metropolitan or rural areas (e.g. Alba and Nee, 2003; Bean and Stevens, 2003, Massey. Durand, 
and Malone, 2002). If the immigrants in these areas are more likely to marry natives and have better labor market outcomes than the immigrants in traditional destinations, then the increasing marriage to a native wage premium may simply be explained by changes in the geography of immigration. To examine this possibility, we add MSA-year fixed effects to the model. In this specification, we are implicitly comparing wages of immigrants living in the same city in the same year with the same observable characteristics.

MSA-year fixed effects will take into account all factors, observable and unobservable, within an MSA in a given year that are constant for everyone in the MSA-year. They will control for variables such as industry structure and unemployment rate. However, two immigrants living in the same city in the same year may experience different labor and marriage markets if they are from different countries of origin. We know from the intermarriage literature that immigrants are less likely to marry natives when they live in areas with large concentrations of co-ethnics (Safi, 2008; Kalmijn and van Tubergen, 2010). We also know that residence in ethnic enclaves is often associated with lower wages (Borjas, 2000; Barry and Miller, 2005; Warman, 2007). ${ }^{6}$ If immigrants that marry natives are becoming less likely to live in ethnic enclaves, then the increasing intermarriage wage premium could simply reflect changes in residential patterns of immigrants that marry natives. To address this issue, we add a variable measuring the share of the MSA population that was born in the immigrant's country of birth, along with its square term, to the model.

Column 3 of Table 1 shows that when both MSA-year fixed effects and the size of country of origin group variables are added to the model, the time pattern in the marriage to native premiums remains the same. The estimates of the coefficients on the size variables indicate that immigrants residing in ethnic enclaves tend to earn lower wages, but the decrease in earnings

\footnotetext{
${ }^{6}$ Quasi-experimental evidence based on the way refugees are placed in different locations in Sweden suggests that living in ethnic enclaves improves labor market outcomes for less skilled immigrants (Edin, Fredriksson, and Åslund, 2003).
} 
is nonlinear in the size variable. Controlling for observable characteristics, in 1980, immigrants married to natives earn 3.3 percent higher wages than immigrants married to other immigrants. In 1990, this differential grew to 6.0 percent, in 2000 to 7.8 , in 2005-2007 to 10.3, and by 20082010 to 12.4 percent. Thus, relative to immigrants married to immigrants, those married to natives have received a fourfold increase in the wages over the past three decades. Estimates of all of the coefficients on the marriage to native interactions are jointly and generally pairwise statistically significantly different from each other at 5\% level. The only exception is that the estimated coefficient on the 1990-marriage to a native interaction is not statistically different from the marriage to a native coefficient suggesting that the returns to intermarriage did not change in a statistically meaningful way between 1980 and 1990.

The results in Table 1 show that adding observable characteristics to the models does not change the main story. Immigrants married to natives do tend to have characteristics that are valued in the labor market and so controlling for variables such as education and English fluency results in smaller estimated intermarriage premiums. However, if anything, adding more variables to the models makes the increasing intermarriage premium pattern stronger. Failing to find evidence that changes in the composition of immigrants married to natives is driving our results, we conclude instead that the characteristics of immigrants that marry natives are becoming more highly valued in the labor market. ${ }^{7}$

\subsection{Heterogeneous Effects}

In this section, we test the robustness of our results by analyzing whether this positive impact is experienced across different demographic groups. We start by separating the sample into four education groups: less than high school, high school degree, some college education, and at least

\footnotetext{
${ }^{7}$ Additional results not shown here suggest that there is no discernable pattern in either the employment or working hours over the past three decades, implying that positive impacts for immigrants married to natives are channeled through wage premiums as opposed to employment premiums.
} 
a college degree. Sample sizes are much smaller in these models, and so it should not be surprising that estimates are not as precise. However, the results in Table 2 broadly suggest that across education levels, immigrants married to natives are becoming more highly rewarded over time. Potentially as a result of smaller samples, we cannot precisely identify year-by-year differences in the returns to marrying natives. However, in all but the college graduate category, returns to marrying a native in 2008 to 2010 are statistically different from the returns in 1980 at at least the $10 \%$ significance level. This is consistent with the literature suggesting that the returns to social and managerial skills have increased for people of all education levels (Kuhn and Weinberger, 2005).

Table 3 separates the sample into four race categories. Results suggest that our baseline findings are driven by whites and Hispanics. There is no clear pattern in the returns to marrying a native over time for blacks and Asians. In fact, for blacks, there is no evidence of an intermarriage premium at all in time periods outside of 2005 to 2007. This is consistent with the segmented assimilation theory (Portes and Zhou, 1993) whereby assimilation can lead to negative outcomes for immigrants in certain groups. However, our sample of black immigrants is quite small given the sample size requirements of any analysis making use of MSA-year fixed effects, and so we do not put too much weight on these results.

\subsection{Mechanisms}

Having shown that intermarriage premiums have increased in the past few decades and that these increases appear very robust across segments of the immigrant population, we now explore whether this pattern can be explained by increases in the returns to education or English language fluency. The education premium has been growing in recent decades (Lemieux, 2008; Boudarbat, Lemieux and Riddell, 2010), especially when comparing college graduates to high school 
graduates (Lemieux, 2008; Acemoğlu and Autor, 2011; Lindley and Machin, 2014). With globalization, English speaking skills may also have become more valued in the labor market.

Table 4 presents results from models adding interactions between the year dummy variables and the language fluency and education variables to our baseline models. The first column adds just the language interaction variables. Estimated coefficients on these interaction terms are all positive and statistically significant suggesting that English skills are valued more highly in recent years than in the past. However, allowing the returns to English fluency to differ by year does not alter our finding of the increasing wage premium trend for immigrants married to natives.

The second column presents a model adding education interaction terms to the baseline specification. Results suggest large increases in the returns to a college education over time. In contrast to our language results, however, adding the education interactions to the model does decrease the magnitude of the increasing intermarriage premium. This suggests that part of the reason immigrants married to natives have increasingly higher wages relative to immigrants that marry other immigrants is that they tend to have college degrees. However, college degrees do not explain the entire increasing intermarriage premium. Even in models including the full set of education interactions, immigrants married to natives have experienced increasingly higher wages relative to immigrants married to other immigrants. Marriage to a native appears to measure unobserved traits and skills that have become increasingly valuable in the labor market.

The last column of Table 4 shows results from a model including the language and education interactions at the same time. The estimated coefficients reflect the same patterns we have already discussed. Estimates are jointly and generally pairwise statistically different from each other at at least 10 percent significance level.

\section{Conclusion}


This paper investigates trends in returns to social and linguistic skills in the U.S. labor market by examining intermarriage wage premiums in the past three decades. Empirical results show that the marriage to a native premium has been increasing over time suggesting that communication and social skills are becoming more highly valued in the labor market. These basic trends do not appear to be driven by changes in the characteristics of immigrants that marry natives since patterns are robust across models which control for different sets of observable characteristics. We certainly acknowledge the possibility that there are unobserved variables driving our results, but it is not obvious what they might be.

We find the increasing intermarriage wage premium among immigrants of all education levels. This should not be surprising given that automation and computerization have increased the returns to communication across the skill distribution. No consistent pattern in intermarriage premiums or penalties was found for Asians and blacks. We find this result intriguing but leave its analysis for future work.

Given that immigrants married to natives tend to have more schooling and are more fluent in English, we then considered whether the increasing intermarriage premium is simply reflecting increasing returns to education or language ability. We found evidence suggesting that immigrants with more schooling and better command of English do have higher relative wages in recent years. However, even in models allowing for increasing returns to these variables, the basic pattern in intermarriage premiums remains the same. This suggests that while part of the reason immigrants married to natives have increasingly higher wages is that they have more schooling and better English language skills, marriage to a native measures additional traits which appear to have become more valuable in the labor market.

Quite a bit of media attention has been given to the idea that recent waves of immigrants are not assimilating at the same speed as immigrants in the past. Borjas (2013) shows that immigrants who entered the U.S. before the 1980s narrowed their initial wage disadvantage by 15\% during their first two decades in the U.S., while recent immigrants had significantly slower 
rates of economic assimilation. He attributes the slower economic integration of recent immigrants partly to their worse English skills. Our empirical results suggest that the slowdown in assimilation rates may not only be about changes in the composition of recent waves of immigrants but instead about economic transitions that increasingly reward communication and social skills.

\section{References}

Acemoğlu, D. and Autor, D. (2011) Skills, Tasks and Technologies: Implications for Employment and Earnings. In Handbook of Labor Economics (Volume 4 ed., pp. 1043). Ashenfelter O. and Card D. eds., Amsterdam: Elsevier.

Aydemir, A. and Skuterud, M. (2005) Explaining the Deteriorating Entry Earnings of Canada's Immigrant Cohorts, 1966- 2000. Canadian Journal of Economics, 38(2): 641-672.

Alba, R.D. and Nee, V. (2003) Remaking the American Mainstream: Assimilation and Contemporary Immigration. Cambridge: Harvard University Press.

Autor, D. H. and Dorn, D. (2013) The Growth of Low-skill Service Jobs and the Polarization of the US Labor Market. American Economic Review, 103(5): 1553-1597.

Autor, D. H. and Handel, M. J. (2013) Putting Tasks to the Test: Human Capital, Job Tasks, and Wages. Journal Of Labor Economics, 31(2): S59-S96.

Autor, D. H., Levy, F. and Murnane, R. J. (2003) The Skill Content of Recent Technological Change: An Empirical Exploration. Quarterly Journal of Economics, 118(4): 1279-1333.

Barry, C. R. and Miller, P. W. (2005) Do Enclaves Matter in Immigrant Adjustment?. City \& Community, 4(1): 5-35. 
Bean, F. D. and Stevens, G. (2003) America's Newcomers and the Dynamics of Diversity. American Sociological Association Rose Series in Sociology.

Borjas, G. J. (2000) Ethnic Enclaves and Assimilation. Swedish Economic Policy Review, 7(2): 89-122.

Borjas, G. J. (2013) The slowdown in the Economic Assimilation of Immigrants: Aging and Cohort Effects Revisited Again. EconLit, EBSCOhost,

Boudarbat, B., Lemieux, T. and Riddell, W. (2010) The Evolution of the Returns to Human Capital in Canada, 1980-2005. Canadian Public Policy, 36(1): 63-89.

Chi, M. and Drewianka, S. (2010) How Much is a Green Card Worth? Evidence from Mexican Men Who Marry Women Born in the U.S. Working Paper.

Duncan, B. and Trejo, S. J. (2011). Intermarriage and the Intergenerational Transmission of Ethnic Identity and Human Capital for Mexican Americans. Journal of Labor Economics, 29(2): 195-227.

Dribe, M. and Nystedt, P. (2014) Is There an Intermarriage Premium for Male Immigrants? Exogamy and Earnings in Sweden 1990-2009. International Migration Review.

Edin, P., Fredriksson, P. and Åslund, O. (2003) Ethnic Enclaves and the Economic Success of Immigrants--Evidence from a Natural Experiment. Quarterly Journal Of Economics, 118(1): 329-357.

Furtado, D. and Theodoropoulos, N. (2009) I'll Marry You if You Get Me a Aob: Marital Assimilation and Immigrant Employment Rates. International Journal of Manpower, 30(12): $116-126$. 
Furtado, D. and Theodoropoulos, N. (2010) Why Does Intermarriage Increase Immigrant Employment? The Role of Networks. B.E. Journal Of Economic Analysis And Policy: Topics In Economic Analysis And Policy, 10(1).

Gevrek, Z. E. (2011) Role of Family Structure in Immigrants' Economic Integration. ProQuest Information \& Learning). Dissertation Abstracts International Section A: Humanities and Social Sciences, 71 (8): 2988-2988.

Kalmijn, M. and van Tubergen, F. (2010) A Comparative Perspective on Intermarriage: Explaining Differences among National-Origin Groups in the United States. Demography, 47(2): 459-479.

Kantarevic, J. (2005) Interethnic Marriages and Economic Assimilation of Immigrants Iza Dp, Bonn, p. 1142.

Kuhn, P. and Weinberger, C. (2005) Leadership Skills and Wages. Journal of Labor Economics, 23(3): 395-436.

Lemieux, T. (2008) The Changing Nature of Wage Inequality. Journal of Population Economics, 21(1): 21-48.

Lindley, J. and Machin, S. (2014) Spatial Changes in Labour Market Inequality. Journal Of Urban Economics, 79121-138.

Massey, D. S., Durand, J. and Malone, N. J. (2002) Beyond Smoke and Mirrors: Mexican Immigration in an Era of Economic Integration. New York: Russell Sage Foundation.

Meng, X. and Gregory, R. G. (2005) Intermarriage and the Economic Assimilation of Immigrants. Journal of Labor Economics, 23(1): 135-175. 
Meng, X. and Meurs, D. (2009) Intermarriage, Language, and Economic Assimilation Process. International Journal of Manpower, 30(1): 127-144.

Nekby, L. (2010) Inter- and Intra-marriage Premiums Revisited: It’s Probably Who You Are, not Who You Marry! IZA DP, (Institute for the Study of Labor (IZA))

Nottmeyer, O. (2010) Does Intermarriage Pay off? A Panel Data Analysis. IZA DP, (Institute for the Study of Labor (IZA))

Portes, A. and Zhou, M. (1993) The New Second Generation: Segmented Assimilation and Its Variants. Annals Of The American Academy Of Political \& Social Science, 53074.

Ruggles, J. S., Alexander, T., Genadek, K., Goeken R., Schroeder, M. B. and Sobek M. (2010) Integrated Public Use Microdata Series: Version 5.0 [Machine-readable database]. Minneapolis: University of Minnesota.

Safi, M. (2008) Intermarriage and Assimilation: Disparities in Levels of Exogamy among Immigrants in France. Population, 63(2): 239-267.

Warman, C. (2007) Ethnic Enclaves and Immigrant Earnings Growth. Canadian Journal Of Economics, 40(2): 401-422.

Weinberger, C. (forthcoming) The Increasing Complementarity between Cognitive and Social Skills. Review of Economics and Statistics. 
Figure 1. Log Hourly Wage of Immigrants Married to Natives and Immigrants Married to Other Immigrants

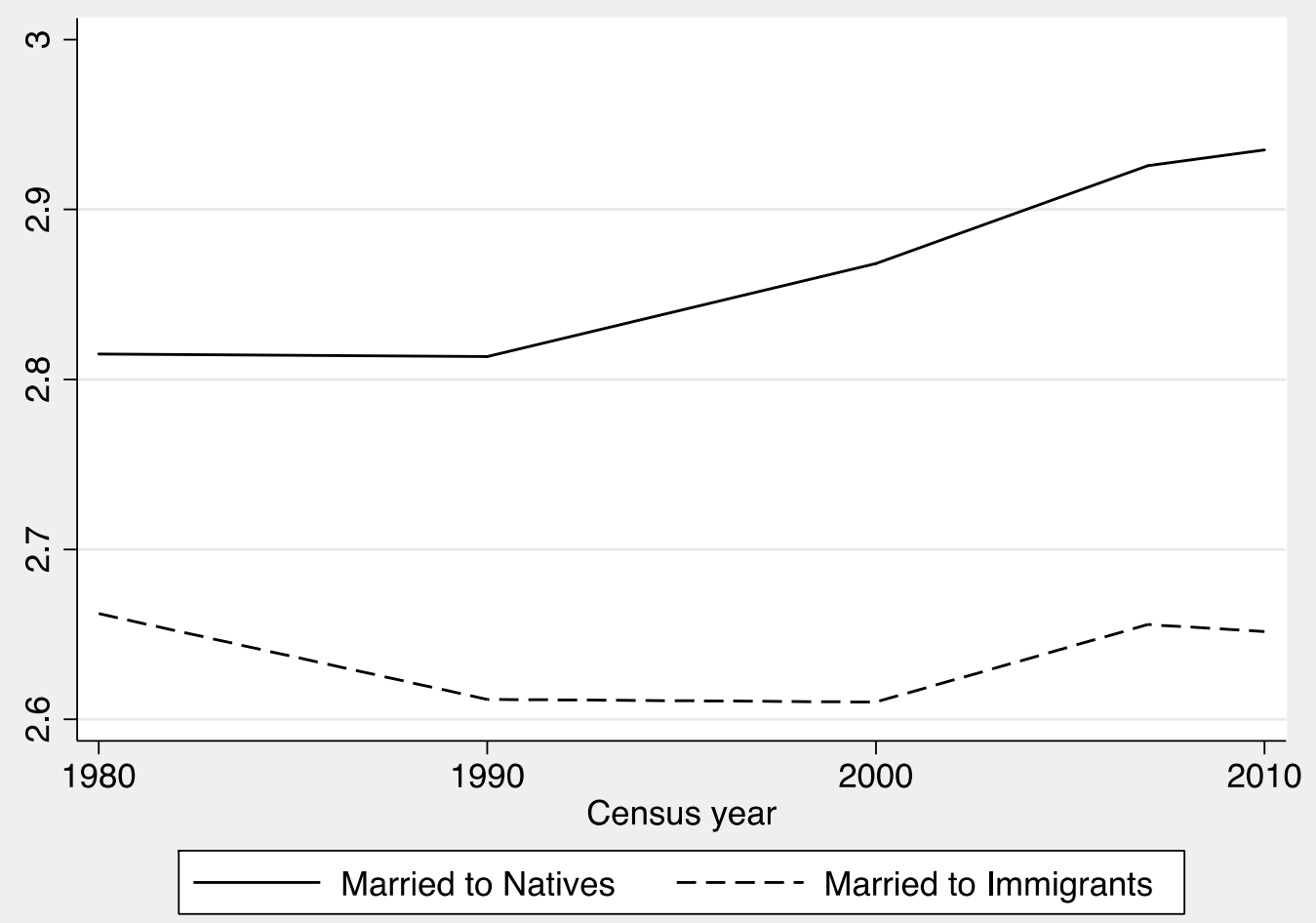


Table 1. Regression Estimates of Marriage to a Native Wage Premiums

\begin{tabular}{|c|c|c|c|}
\hline Dependent Variable: Hourly Wage & 1 & 2 & 3 \\
\hline Marriage to a Native & $\begin{array}{l}0.171^{* * *} \\
(0.011)\end{array}$ & $\begin{array}{l}0.025^{* * *} \\
(0.010)\end{array}$ & $\begin{array}{l}0.033^{* * *} \\
(0.010)\end{array}$ \\
\hline Marriage to a Native $\times 1990$ & $\begin{array}{l}0.042^{* * * *} \\
(0.014)\end{array}$ & $\begin{array}{l}0.021^{*} \\
(0.012)\end{array}$ & $\begin{array}{l}0.027^{* *} \\
(0.012)\end{array}$ \\
\hline Marriage to a Native $\times 2000$ & $\begin{array}{l}0.109^{* * *} \\
(0.013)\end{array}$ & $\begin{array}{l}0.051^{* * *} \\
(0.011)\end{array}$ & $\begin{array}{l}0.045^{* * *} \\
(0.012)\end{array}$ \\
\hline Marriage to a Native $\times 2005-2007$ & $\begin{array}{c}0.122^{* * * *} \\
(0.014)\end{array}$ & $\begin{array}{c}0.077^{* * *} \\
(0.012)\end{array}$ & $\begin{array}{c}0.070^{* * * *} \\
(0.013)\end{array}$ \\
\hline Marriage to a Native $\times 2008-2010$ & $\begin{array}{l}0.123^{* * *} \\
(0.014)\end{array}$ & $\begin{array}{c}0.093^{* * *} \\
(0.012)\end{array}$ & $\begin{array}{l}0.091^{* * * *} \\
(0.012)\end{array}$ \\
\hline Age & - & $\begin{array}{l}0.059^{* * * *} \\
(0.001)\end{array}$ & $\begin{array}{l}0.055^{* * *} \\
(0.001)\end{array}$ \\
\hline $\operatorname{Age}^{2}$ & - & $\begin{array}{l}-0.001^{* * *} \\
(0.000)\end{array}$ & $\begin{array}{c}-0.001^{* * *} \\
(0.000)\end{array}$ \\
\hline High School & - & $\begin{array}{l}0.175^{* * *} \\
(0.044)\end{array}$ & $\begin{array}{l}0.136^{* * *} \\
(0.004)\end{array}$ \\
\hline Some College & - & $\begin{array}{l}0.359^{* * *} \\
(0.005)\end{array}$ & $\begin{array}{l}0.290^{* * * *} \\
(0.005)\end{array}$ \\
\hline College Degree & - & $\begin{array}{l}0.782^{* * * *} \\
(0.005)\end{array}$ & $\begin{array}{l}0.663^{* * * *} \\
(0.059)\end{array}$ \\
\hline Children in the Household & - & $\begin{array}{l}0.032^{* * * *} \\
(0.004)\end{array}$ & $\begin{array}{c}0.049^{* * *} \\
(0.004)\end{array}$ \\
\hline Veteran & - & $\begin{array}{c}0.009^{*} \\
(0.005)\end{array}$ & $\begin{array}{l}0.015^{* * *} \\
(0.005)\end{array}$ \\
\hline English Fluency & - & $\begin{array}{l}0.046^{* * *} \\
(0.004)\end{array}$ & $\begin{array}{l}0.055^{* * *} \\
(0.004)\end{array}$ \\
\hline Years in U.S. & - & $\begin{array}{l}0.006^{* * *} \\
(0.000)\end{array}$ & $\begin{array}{l}0.006^{* * * *} \\
(0.000)\end{array}$ \\
\hline Size of Origin Group & - & - & $\begin{array}{c}-0.148^{* * *} \\
(0.043)\end{array}$ \\
\hline Size of Origin Group ${ }^{2}$ & - & - & $\begin{array}{l}0.130^{* *} \\
(0.058)\end{array}$ \\
\hline MSA-Year Fixed Effects & No & No & Yes \\
\hline $\mathrm{R}^{2}$ & 0.043 & 0.357 & 0.391 \\
\hline Observations & 163,774 & 163,774 & 163,774 \\
\hline
\end{tabular}

Notes: The sample consists of married, foreign born males between the ages of 18 and 64 who immigrated to the U.S. before the age of 18, are not currently enrolled in school, reside in an identifiable metropolitan statistical area, work full time and full year, and earn an hourly wage between \$2 and \$200 in 1990 dollars. The English fluency dummy variable equals one if the person speaks only English, or speaks English very well, or speaks English well. Size of origin group refers to the share of the MSA population born in the same country as the immigrant. Significance levels are noted by the following: * significant at 10 percent; ** significant at 5 percent; *** significant at 1 percent. 
Table 2. Regression Estimates of Marriage to a Native Wage Premiums by Education

\begin{tabular}{lcccc}
$\begin{array}{l}\text { Dependent Variable: Hourly } \\
\text { Wage }\end{array}$ & $\begin{array}{c}\text { Less Than High } \\
\text { School }\end{array}$ & $\begin{array}{c}\text { High School } \\
\text { Degree }\end{array}$ & Some College & College Degree \\
\hline Marriage to a Native & $0.037^{*}$ & $0.053^{* * *}$ & $0.041^{*}$ & $0.058^{* * *}$ \\
& $(0.020)$ & $(0.018)$ & $(0.024)$ & $(0.023)$ \\
Marriage to a Native $\times 1990$ & 0.023 & 0.028 & 0.006 & -0.001 \\
& $(0.025)$ & $(0.022)$ & $(0.028)$ & $(0.028)$ \\
Marriage to a Native $\times 2000$ & 0.019 & 0.031 & 0.037 & $(0.002$ \\
Marriage to a Native $\times$ & $(0.024)$ & $(0.020)$ & $0.026)$ \\
2005-2007 & 0.043 & $0.040^{*}$ & $(0.029)$ & 0.023 \\
Marriage to a Native $\times$ & $(0.027)$ & $(0.022)$ & 0.045 & $(0.028)$ \\
2008-2010 & $0.066^{* * *}$ & $0.060^{* * *}$ & $(0.029)$ & $(0.027)$ \\
$\mathrm{R}^{2}$ & $(0.026)$ & $(0.021)$ & 0.190 & 0.157 \\
Observations & 0.201 & 0.223 & 31,018 & 42,598 \\
\hline
\end{tabular}

Notes: The sample consists of married, foreign born males between the ages of 18 and 64 who immigrated to the U.S. before the age of 18, are not currently enrolled in school, reside in an identifiable metropolitan statistical area, work full time and full year, and earn an hourly wage between \$2 and \$200 in 1990 dollars. Significance levels are noted by the following: * significant at 10 percent; ** significant at 5 percent; *** significant at 1 percent.

Table 3. Regression Estimates of Marriage to a Native Wage Premiums by Race

\begin{tabular}{lcccc}
\hline \multicolumn{1}{c}{$\begin{array}{c}\text { Dependent Variable: } \\
\text { Hourly Wage }\end{array}$} & White & Black & Asian & Hispanics \\
\hline Marriage to a Native & $0.021^{* *}$ & -0.067 & $0.122^{* *}$ & $0.038^{* *}$ \\
Marriage to a Native $\times$ & $(0.011)$ & $(0.084)$ & $(0.048)$ & $(0.016)$ \\
1990 & $0.030^{* *}$ & 0.065 & -0.030 & 0.019 \\
Marriage to a Native $\times$ & $(0.014)$ & $(0.101)$ & $(0.056)$ & $(0.019)$ \\
2000 & $0.054^{* * *}$ & 0.084 & -0.047 & $0.038^{* *}$ \\
Marriage to a Native $\times$ & $(0.013)$ & $(0.095)$ & $(0.054)$ & $(0.017)$ \\
2005-2007 & $0.078^{* * *}$ & $0.187^{*}$ & -0.062 & $0.062^{* * *}$ \\
Marriage to a Native $\times$ & $(0.015)$ & $(0.100)$ & $(0.054)$ & $0.019)$ \\
2008-2010 & $0.100^{* * *}$ & 0.025 & 0.037 & $(0.018)$ \\
$\mathrm{R}^{2}$ & $(0.014)$ & $(0.097)$ & $(0.052)$ & 0.334 \\
Observations & 0.396 & 0.448 & 0.359 & 91,276 \\
\hline
\end{tabular}

Note: The sample consists of married, foreign born males between the ages of 18 and 64 who immigrated to the U.S. before the age of 18, are not currently enrolled in school, reside in an identifiable metropolitan statistical area, work full time and full year, and earn an hourly wage between \$2 and \$200 in 1990 dollars. Significance levels are noted by the following: * significant at 10 percent; ** significant at 5 percent; $* * *$ significant at 1 percent 
Table 4. Regression Estimates of Marriage to a Native Wage Premiums, English Fluency Premiums, and Education Premiums

\begin{tabular}{|c|c|c|c|}
\hline Dependent Variable: Hourly Wage & 1 & 2 & 3 \\
\hline Marriage to a Native & $\begin{array}{l}0.022^{* * *} \\
(0.011)\end{array}$ & $\begin{array}{l}0.061^{* * *} \\
(0.010)\end{array}$ & $\begin{array}{l}0.048^{* * *} \\
(0.010)\end{array}$ \\
\hline Marriage to a Native $\times 1990$ & $\begin{array}{l}0.032^{* * * *} \\
(0.013)\end{array}$ & $\begin{array}{c}0.011 \\
(0.013)\end{array}$ & $\begin{array}{c}0.017^{* * *} \\
(0.013)\end{array}$ \\
\hline Marriage to a Native $\times 2000$ & $\begin{array}{c}0.055^{* * *} \\
(0.012)\end{array}$ & $\begin{array}{c}0.019^{*} \\
(0.012)\end{array}$ & $\begin{array}{c}0.032^{* * * *} \\
(0.012)\end{array}$ \\
\hline Marriage to a Native $\times 2005-2007$ & $\begin{array}{l}0.084^{* * *} \\
(0.013)\end{array}$ & $\begin{array}{l}0.034^{* * *} \\
(0.013)\end{array}$ & $\begin{array}{c}0.051^{* * * *} \\
(0.013)\end{array}$ \\
\hline Marriage to a Native $\times 2008-2010$ & $\begin{array}{l}0.103^{* * *} \\
(0.012)\end{array}$ & $\begin{array}{c}0.057^{* * *} \\
(0.012)\end{array}$ & $\begin{array}{c}0.072^{* * *} \\
(0.013)\end{array}$ \\
\hline English Fluency $\times 1990$ & $\begin{array}{l}0.027^{* *} \\
(0.013)\end{array}$ & - & $\begin{array}{l}0.028^{* *} \\
(0.012)\end{array}$ \\
\hline English Fluency $\times 2000$ & $\begin{array}{l}0.046^{* * *} \\
(0.012)\end{array}$ & - & $\begin{array}{l}0.056^{* * *} \\
(0.012)\end{array}$ \\
\hline English Fluency $\times 2007$ & $\begin{array}{c}0.067^{* * *} \\
(0.013)\end{array}$ & - & $\begin{array}{c}0.074^{* * *} \\
(0.013)\end{array}$ \\
\hline English Fluency $\times 2010$ & $\begin{array}{l}0.056^{* * *} \\
(0.012)\end{array}$ & - & $\begin{array}{l}0.066^{* * *} \\
(0.012)\end{array}$ \\
\hline College Degree $\times 1990$ & - & $\begin{array}{c}0.180^{* * *} \\
(0.018)\end{array}$ & $\begin{array}{c}0.179^{* * * *} \\
(0.018)\end{array}$ \\
\hline College Degree $\times 2000$ & - & $\begin{array}{c}0.252^{* * *} \\
(0.017)\end{array}$ & $\begin{array}{c}0.257^{* * *} \\
(0.017)\end{array}$ \\
\hline College Degree $\times 2007$ & - & $\begin{array}{l}0.309^{* * *} \\
(0.018)\end{array}$ & $\begin{array}{c}0.315^{* * *} \\
(0.018)\end{array}$ \\
\hline College Degree $\times 2010$ & - & $\begin{array}{l}0.312^{* * * *} \\
(0.017)\end{array}$ & $\begin{array}{l}0.317^{* * *} \\
(0.017)\end{array}$ \\
\hline Some College $\times 1990$ & - & $\begin{array}{l}0.077^{* * *} \\
(0.017)\end{array}$ & $\begin{array}{l}0.074^{* * *} \\
(0.017)\end{array}$ \\
\hline Some College $\times 2000$ & - & $\begin{array}{l}0.081^{* * *} \\
(0.016)\end{array}$ & $\begin{array}{c}0.082^{* * *} \\
(0.017)\end{array}$ \\
\hline Some College $\times 2007$ & - & $\begin{array}{c}0.117^{* * *} \\
(0.018)\end{array}$ & $\begin{array}{c}0.116^{* * *} \\
(0.018)\end{array}$ \\
\hline Some College $\times 2010$ & - & $\begin{array}{l}0.090^{* * * *} \\
(0.017)\end{array}$ & $\begin{array}{l}0.089^{* * * *} \\
(0.017)\end{array}$ \\
\hline High School $\times 1990$ & - & $\begin{array}{c}0.018 \\
(0.015)\end{array}$ & $\begin{array}{c}0.015 \\
(0.016)\end{array}$ \\
\hline High School $\times 2000$ & - & $\begin{array}{l}-0.004 \\
(0.014)\end{array}$ & $\begin{array}{l}-0.004 \\
(0.014)\end{array}$ \\
\hline High School $\times 2007$ & - & $\begin{array}{c}0.010 \\
(0.015)\end{array}$ & $\begin{array}{c}0.007 \\
(0.015)\end{array}$ \\
\hline High School $\times 2010$ & - & $\begin{array}{l}-0.007 \\
(0.015)\end{array}$ & $\begin{array}{l}-0.009 \\
(0.015)\end{array}$ \\
\hline $\begin{array}{l}\mathrm{R}^{2} \\
\text { Observations }\end{array}$ & $\begin{array}{c}0.391 \\
163,774\end{array}$ & $\begin{array}{c}0.393 \\
163,774\end{array}$ & $\begin{array}{c}0.393 \\
163,774\end{array}$ \\
\hline
\end{tabular}

Note: The sample consists of married, foreign born males between the ages of 18 and 64 who immigrated to the U.S. before the age of 18, are not currently enrolled in school, reside in an identifiable metropolitan statistical area, work full time and full year, and earn an hourly wage between \$2 and \$200 in 1990 dollars. The English fluency dummy variable equals one if the person speaks only English, or speaks English very well, or speaks English well. Size of origin group refers to the share of the MSA population born in the same country as the immigrant. Significance levels are noted by the following: * significant at 10 percent; ** significant at 5 percent; *** significant at 1 percent. 